\title{
Chromium and Nickel Accumulation by Plants Along an Altitudinal Gradient in Western Carpathian Secondary Spruce Stands
}

\author{
Margita Kuklová*, Ján Kukla, Katarína Gašová \\ Institute of Forest Ecology of the Slovak Academy of Sciences, \\ Štúrova 2, 96053 Zvolen, Slovak Republic
}

Received: 4 November 2015

Accepted: 7 March 2016

\begin{abstract}
Our research was realized in segments of 80 -year-old secondary spruce ecosystems selected in the buffer zone of Slovenský raj NP (western Carpathians). The vertical transect (635-1,110 m a.s.1.) consisted of three localities with six geobiocoenological plots. The Cr contents $\left(\mathrm{mg} \mathrm{kg}^{-1}\right)$ found in surface humus $(0.38 \pm 0.04-2.18 \pm 0.22)$ and Ao horizons $(0.20 \pm 0.03-3.16 \pm 0.32)$ of Skeli-Humic Podzols and Dystric Cambisols were nearly the same, in contrast to Ni $(5.27 \pm 0.47-22.41 \pm 2.02$ and $0.81 \pm 0.07$ $3.75 \pm 0.34 \mathrm{mg} \mathrm{kg}^{-1}$, respectively). Ni contents in Ool and Oof horizons of surface humus with altitude as a rule decreased, while in Ooh horizon increased. For $\mathrm{Cr}$ a similar dependence was not observed. $\mathrm{The} \mathrm{Cr}$ contents in plants (Dryopteris dilatata, Luzula luzuloides, Prenanthes purpurea, Rubus idaeus, Senecio ovatus, Solidago virgaurea, Vaccinium myrtillus) were usually lower than $0.4-0.5 \mathrm{mg} \mathrm{kg}^{-1}$, with the exception of $V$. myrtillus $\left(>1.1 \mathrm{mg} \mathrm{kg}^{-1}\right)$ at 1,110 $\mathrm{m}$ a.s.l. On the other hand, Ni content was mostly higher as background value $\left(1.5 \mathrm{mg} \mathrm{kg}^{-1}\right)$, and in the case of $S$. virgaurea up above $10 \mathrm{mg} \mathrm{kg}^{-1}$ at $650 \mathrm{~m}$ a.s.1. The highest mean Ni content was found in S. ovatus, and it significantly $(\mathrm{p}<0.05)$ differed from those found in $V$. myrtillus and $L$. luzuloides (fertile) shoots. Stronger positive linear correlations were between $\mathrm{Cr}$ content in soils and shoots of D. dilatata and L. luzuloides (sterile). For Ni, it was R. idaeus. Ni transfer coefficients (TC) found for five plants (L. luzuloides - sterile, R. idaeus, D. dilatata, S. ovatus, S. virgaurea) rooted in surface horizons of Cambisols were higher than 1, thus pointing at the impact of soil contamination. Cr TC higher than 1 were found for D. dilatata (2.4) and V. myrtillus (1.1.-3.6) rooted in the surface horizons of Podzols, indicating the better bio-accumulation ability of these plants.
\end{abstract}

Keywords: spruce ecosystems, altitude, soils, plants, heavy metals

*e-mail: kuklova@savzv.sk 


\section{Introduction}

Central European forest ecosystems have long been faced with excessive amounts of various chemical substances. Pollution by heavy metals in the environment is mainly derived from anthropogenic sources [1]. Plants may absorb toxic metals from soil as well as from metal deposits on the surfaces of plant parts exposed to a polluted environment [2]. The process of metal intake by plants depends mainly on the chemical form in which the metal is bound, its solubility, and toxicity. This involves the mobilization of toxic elements in the soil solution, the decrease of biological activity of soil, and changes in the decomposition of organic matter [3].

Recent years have seen a growth in interest in studying the ability of plant species to accumulate risk elements [4-5]. Due to wide industrial use, $\mathrm{Cr}$ and $\mathrm{Ni}$ have a very negative environmental impact. Chromium is found in all parts of the environment - primarily in the air, water, and soil [6]. Migration of $\mathrm{Cr}$ in soils is conditioned principally by the level of soil contamination, organic matter content, and rainwater acidity [7]. In some plant species $\mathrm{Cr}$ can be significantly absorbed by roots, but its transport to other parts is usually slow [8].

The uptake of metals by plants is largely influenced by their bioavailability, which is determined by both external and internal factors [9]. It has been established that $\mathrm{Cr}$ compounds are highly toxic to plants and are detrimental to their growth and development, but some plants have demonstrated the ability to uptake, translocate, and tolerate even higher concentrations of $\mathrm{Cr}$ [10-11]. Other findings from $\mathrm{Cr}$ distribution in plants indicate that only a small proportion of $\mathrm{Cr}$ can be absorbed and translocated to aerial parts [12-13]. In aerial parts of the plants a higher uptake was observed when the initial supply was in the form of $\mathrm{Cr}(\mathrm{VI})$ [14].

Concentrations of $\mathrm{Ni}$ in surface soils can reflect the impact of both soil-forming processes and anthropogenic activities [15]. The bioavailability of Ni to plants especially varies with the soil properties [16]. The important factor modulating the availability of $\mathrm{Ni}$ for plants is soil $\mathrm{pH}$ [17]. In several populations of Alyssum species the shoot content of $\mathrm{Ni}$ was shown to increase at the elevated $\mathrm{pH}$ values of soil solution [18]. In general, higher plants need $\mathrm{Ni}$, and therefore this element is classified among the essential micronutrients. Nevertheless, the effect of nickel on plants varies according to plant species, their developmental stage, physiological characteristics, and cultivation conditions. Among the plants accumulating $\mathrm{Ni}$, there are hyper-accumulators that accumulate metals in the shoots to the level of over $1,000 \mathrm{mg} \mathrm{kg}^{-1}$ [19].

The forest ecosystems of northern Slovenský Raj National Park (in the western Carpathians) are affected by air pollutants produced by various anthropogenic activities. Operators of industrial activity (non-ferrous metal smelting, mining, and mineral processing) in the district of Spišská Nová Ves city belong among the 100 largest sources of air pollution in the Slovak Republic (www.air.sk). According to producer data, the lowest annual emission of solid pollutants was measured in 2005 (43.793 $\mathrm{t} \mathrm{year}^{-1}$ ) and the highest in 2003 (49.784 $\mathrm{t} \mathrm{year}^{-1}$ ). Based on environmental regionalization, the mid-Spiš area was classified as hygienically harmful, where dominating contaminants are heavy metals [20]. The impact of longterm cultivation of spruce monocultures in this region together with the effects of acid atmospheric pollutants caused the strong acidification of topsoil horizons [21]. Exceeded reference values for contents of $\mathrm{Cr}$ and $\mathrm{Ni}$ were observed in soils of the Richnava area [20]. Some studies have shown that concentrations of $\mathrm{Pb}$ and $\mathrm{Cd}$ found in Vaccininium myrtillus, Dryopteris dilatata, Luzula luzuloides, and Rubus idaeus species growing in the buffer zone of Slovenský Raj National Park were within the toxicity range. The limit values calculated for humus and mineral soil horizons have been exceeded only in the case of $\mathrm{Hg}$ [22]. The values of transfer coefficients of selected risk elements found in bilberry aboveground phytomass showed that $\mathrm{Al}, \mathrm{Cr}$, and $\mathrm{Ni}$ were better accumulated by bilberry growing on acid Podzols compared to less acidic Cambisols [23-24].

Plant growth can be chiefly expressed as a function of genotype and environment, i.e., of external and internal growth factors [6]. Some plants have the ability to selectively uptake and accumulate specific elements of large quantities and thus are sensitive indicators of a particular element. In an ecosystem the paths and whereabouts of the elements may be influenced in a specific manner by organism activity [25]. Also, elevation differences can lead to corresponding changes in environmental factors such as temperature, precipitation, and soil type, which makes the growing environment of plants more complex [26]. In this connection, the present study was undertaken with the objectives of:

1. Determining if there is a significant difference in loading of plants by chromium and nickel among the spruce stands as differed by their soil types.

2. To evaluate the transfer of these elements into aboveground shoots of dominant plant species (Luzula luzuloides (Lam.) Dandy et Wilmott, Vaccinium myrtillus L., Dryopteris dilatata (Hoffm.) A. Gray, Prenanthes purpurea L., Rubus idaeus L., Senecio ovatus (P. Gaertn., B. Mey. et Scherb.) Willd., Solidago virgaurea $\mathrm{L}$.) of the spruce forests.

3. To specify the trends in changes of element concentrations in relation to altitude.

\section{Material and Methods}

\section{Site Description}

The research was realised in segments of 80-year-old secondary spruce ecosystems selected near Spišská Nová Ves city in the buffer zone of Slovenský Raj National Park. The vertical transect (635-1,110 $\mathrm{m}$ a.s.1.) consisted of three localities with six geobiocoenological plots (Fig. 1, Table 1). Determination and classification of studied geobiocoenoses was made in terms of Zlatník [27]. The importance 


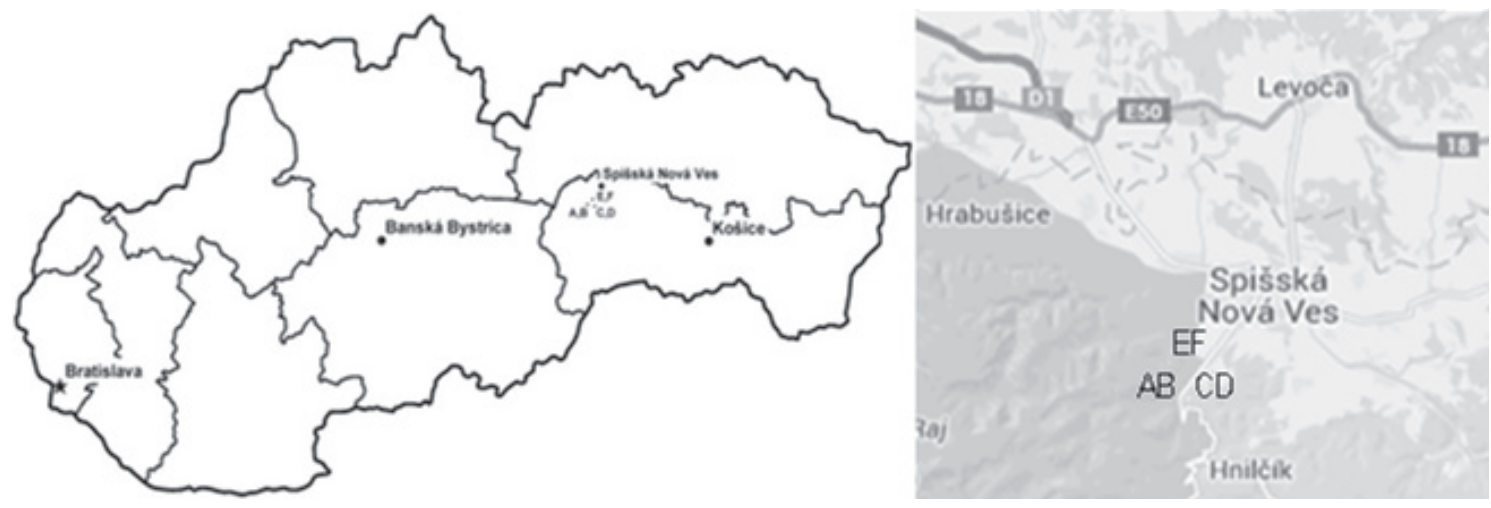

Fig. 1. Locations of the parallel research plots (A-B, C-D, E-F) along an altitudinal gradient.

of species in plant communities was evaluated according to the Braun-Blanquet combined scale of abundance and dominance modified by Zlatník [28]. Geobiocenological units represent segments of reconstructed ecosystems existing continually in the form of segments of "permanent ecological conditions" even after total destruction of natural vegetation. The vegetation grades were determined based on the presence and/or absence of plant species that are able to indicate the differences in moisture of normally developed (neither shallow, nor poorly drained) soils and ambient air, as well as differences in the amount of heat accessible for plant species. This is a significant difference compared with geobotany, where the boundaries of altitudinal vegetation zones are determined non-ecologically on the basis of subjectively specified ranges of altitude used in geomorphology.

Table 1. Basic information on studied forest ecosystems ( $\mathrm{Oo}=$ subhorizons of surface humus, Ao = organo-mineral horizons).

\begin{tabular}{|c|c|c|c|c|c|c|c|c|}
\hline \multicolumn{3}{|c|}{ Monitoring plot } & A & B & $\mathrm{C}$ & D & $\mathrm{E}$ & $\mathrm{F}$ \\
\hline \multicolumn{3}{|c|}{ Altitude (m) } & 1,110 & 1,080 & 960 & 950 & 650 & 635 \\
\hline \multicolumn{3}{|c|}{ Geographical coordinates } & \multicolumn{2}{|c|}{$\begin{array}{l}48^{\circ} 52^{\prime} 26^{\prime \prime} \\
20^{\circ} 28^{\prime} 13^{\prime \prime}\end{array}$} & \multicolumn{2}{|c|}{$\begin{array}{l}48^{\circ} 51^{\prime} 55^{\prime \prime} \\
20^{\circ} 31^{\prime} 13^{\prime \prime}\end{array}$} & \multicolumn{2}{|c|}{$\begin{array}{l}48^{\circ} 53^{\prime} 36^{\prime \prime} \\
20^{\circ} 30^{\prime} 26^{\prime \prime}\end{array}$} \\
\hline \multicolumn{3}{|c|}{ Forest vegetation grade } & \multicolumn{2}{|c|}{ 6. spruce-beech-fir } & \multicolumn{4}{|c|}{ 5. fir-beech } \\
\hline \multicolumn{3}{|c|}{ Edaphic-trophic order/interorder } & \multicolumn{2}{|c|}{ oligotrophic } & \multicolumn{4}{|c|}{ hemioligotrophic } \\
\hline \multicolumn{3}{|c|}{ Groups of geobiocoene types } & \multicolumn{2}{|c|}{ Fageta abietino-piceosa } & \multicolumn{4}{|c|}{ Abieti-Fageta inferiora } \\
\hline \multicolumn{3}{|c|}{ Current tree species composition } & \multicolumn{6}{|c|}{ Picea excelsa (L.) H. Karst. (100\%) } \\
\hline \multicolumn{3}{|c|}{ Stand canopy (\%) } & 40 & 60 & $30-50$ & $70-80$ & 70 & $30-40$ \\
\hline \multicolumn{3}{|c|}{ Parent rock } & $\begin{array}{c}\text { polymict } \\
\text { conglomerates }\end{array}$ & $\begin{array}{l}\text { violet-grey } \\
\text { schist }\end{array}$ & \multicolumn{2}{|c|}{$\begin{array}{c}\text { quartz } \\
\text { conglomerates }\end{array}$} & \multicolumn{2}{|c|}{ grey schist } \\
\hline \multicolumn{3}{|c|}{ Soil unit } & \multicolumn{2}{|c|}{ Skeli-Humic Podzol } & \multicolumn{4}{|c|}{ Dystric Cambisol } \\
\hline \multirow{4}{*}{\multicolumn{2}{|c|}{$\mathrm{pH}_{\mathrm{H} 2 \mathrm{O}}$}} & Ool & 4.52 & 4.11 & \multirow{2}{*}{3.74} & \multirow{2}{*}{4.11} & 4.52 & 4.52 \\
\hline & & Oof & 4.19 & 3.65 & & & 4.05 & 4.19 \\
\hline & & Ooh & 3.75 & 3.61 & 3.79 & 3.65 & - & - \\
\hline & & Ao & 3.22 & 3.52 & 3.55 & 3.62 & 3.72 & 4.11 \\
\hline $\mathrm{C}$ & \multirow{2}{*}{$(\%)$} & \multirow{7}{*}{ Ao } & 4.26 & 7.06 & 8.08 & 5.31 & 4.74 & 5.32 \\
\hline $\mathrm{N}$ & & & 0.22 & 0.18 & 0.46 & 0.31 & 0.27 & 0.30 \\
\hline $\mathrm{Ca}^{2+}$ & \multirow{5}{*}{$\left(\mathrm{mg} \mathrm{kg}^{-1}\right)$} & & 280.56 & 212.42 & 250.50 & 92.18 & 194.39 & 386.77 \\
\hline $\mathrm{Mg}^{2+}$ & & & 51.04 & 36.46 & 66.84 & 32.81 & 37.67 & 53.47 \\
\hline $\mathrm{K}^{+}$ & & & 54.74 & 66.47 & 86.02 & 50.83 & 54.74 & 46.92 \\
\hline $\mathrm{Na}^{2+}$ & & & 25.29 & 20.69 & 22.99 & 20.69 & 18.39 & 13.79 \\
\hline $\mathrm{H}^{+}$ & & & 10.48 & 20.36 & 36.18 & 23.18 & 33.97 & 20.96 \\
\hline
\end{tabular}


Determination and classification of soil units was made according to Societas Pedologica Slovaca and WRB [29-30]. Results from previous studies [21] showed that the active soil reaction in the surface humus layers of skeli-humic podzol situated at 1,000-1,110 $\mathrm{m}$ a.s.l. varied from 3.6 to 4.5 , and in organic-mineral soil layers between 3.2-3.5. The active reaction in the surface humus layers of dystric cambisols situated at an altitude of 950-960 m ranges from 3.7 to 4.1 , in organo-mineral layers between 3.5-3.6, and those at 635-650 $\mathrm{m}$ a.s.1. are between 4.1-4.5 in the surface humus, and 3.7-4.1 in the organic-mineral layers.

The quality of humus in topsoil layers is very unfavourable. It documents the values of $\mathrm{C} / \mathrm{N}$ ratio, which in organic-mineral horizons (Ao) reach 17-39. Content of exchangeable soil cations on study plots also is not optimal. The proportion of calcium to the actual content of exchangeable cations accounted for $42-74 \%$, magnesium $10-15 \%$, potassium $9-23 \%$, sodium $2-9 \%$, and hydrogen $2-11 \%$. The proportion of $\mathrm{Ca}^{2+}$ and $\mathrm{Mg}^{2+}$ was generally low (with the exception of plot $\mathrm{F}$, respectively D), while proportions of $\mathrm{K}^{+}, \mathrm{Na}^{2+}$, and $\mathrm{H}^{+}$were high [21].

The influence of long-term cultivation of spruce monocultures, together with the presence of acid atmospheric pollutants, caused the active reaction of the A horizons of cambisols to drop below a value of 3.9, which means into the oligotrophic order of geobiocoens. So the humus horizons of cambisols have at present the same dynamics of active reaction as the humus horizons of podzols. However, the process of podzolization is still reversible because the albic horizon typical for podzols was not still formed [21].

\section{Soil Material and Data Collection}

Soil samples were taken from horizons of surface humus (Ool - litter, Oof - fermentation, Ooh - humification) and organic-mineral Ao horizons $(2-6 \mathrm{~cm})$ in triplicate. Within these layers are concentrated maximum amounts of pollutants and also of roots of herb species. The thickness of Oo and Ao horizons varied as follows: plot $\mathrm{A}-\mathrm{Oo}$ $12 \mathrm{~cm}$, Ao $13 \mathrm{~cm}$; plot B - Oo $7 \mathrm{~cm}$, Ao $12 \mathrm{~cm}$; plot C - Oo $5 \mathrm{~cm}$, Ao $9 \mathrm{~cm}$; plot D - Oo $5 \mathrm{~cm}$, Ao $7 \mathrm{~cm}$; plot E - Oo $5 \mathrm{~cm}$, Ao $8 \mathrm{~cm}$; plot F - Oo $4 \mathrm{~cm}$, Ao $8 \mathrm{~cm}$. Cambisols situated at 635-650 $\mathrm{m}$ a.s.1. have not developed Ooh subhorizons, which may be related to the faster decomposition of surface humus. The samples were dried, homogenized, and sieved with a $2-\mathrm{mm}$ mesh. Active soil reaction was determined using an Inolab pH 720 digital pH-meter (ratio of fine earth to water solution 1:2.5; in case of surface humus 1:10). Total carbon $(\mathrm{C})$ and nitrogen $(\mathrm{N})$ were estimated by an NCS-FLASH 1112 analyzer (Hanau, Germany). Concentrations of soil-exchangeable $\mathrm{Ca}, \mathrm{Mg}, \mathrm{K}$, and $\mathrm{Na}$ were determined in leachate of $0.1 \mathrm{M} \mathrm{BaCl}_{2}$ by atomic absorption spectrometer. $\mathrm{Cr}$ and $\mathrm{Ni}$ in soil samples were determined in leachate of $2 \mathrm{M} \mathrm{HNO}_{3}$ (soil-to-extractant ratio 1:10 w/v, shaking for two hours and filtration) by atomic absorption spectroscopy (AAS) using Varian Spectr. AA 300/400.

\section{Plant Material and Data Collection}

In the herb synusia of studied plant communities with coverage more than $25 \%$ dominated oligotrophic and hemioligotrophic species like Avenella flexuosa (L.) Parl., Vaccinium myrtillus L., and Luzula luzuloides (Lam.) Dandy et Wilmott. They occur together with species tolerating acidic soil environments as Dryopteris dilatata (Hoffm.) A. Gray, Rubus idaeus L., Maianthemum bifolium (L.) Schm., Oxalis acetosella L., Prenanthes purpurea L., Senecio ovatus (P. Gaertn., B. Mey. et Scherb.) Willd., and Solidago virgaurea L. Oligotrophic species are bound specifically to mineral-poor soil, usually strongly acidic $\left(\mathrm{pH}_{\mathrm{H} 2 \mathrm{O}}\right.$ below 3.9) with a slowdown humification and high accumulation of surface humus. Hemioligotrophic species occupy areas on mineral-less rich, acidic soils ( $\mathrm{pH}$ 3.9-4.9), while acido-tolerant species are only well tolerated to increased acidity of soils.

Previous studies were targeted on the evaluation of relations among contents of heavy metals in the whole soil profiles and in selected herb species with an emphasis on identifying the differences between undamaged and bark beetle-damaged plots [22-24]. For the purposes of this work plant samples were obtained from an area of $400 \mathrm{~m}^{2}$ on each of six representative geobiocoenological plots in the first half of July 2003. Samples were taken from patches with similar canopies. We collected 20 to 25 aboveground shoots from 3-4 experimental squares (1x1 m) depending on the variability of species and their cover. The content of risk elements was repeatedly detected in assimilatory organs of the following plants: (plot A $-V$. myrtillus, L. luzuloides, $R$. idaeus, D. dilatata; plot B - V. myrtillus, R. idaeus, D. dilatata; plot C - V. myrtillus, L. luzuloides, R. idaeus, D. dilatata, S. virgaurea; plot D - V. myrtillus, L. luzuloides, R. idaeus, D. dilatata; plot E-L. luzuloides, $R$. idaeus, S. virgaurea, S. ovatus, P. purpurea; and plot F - L. luzuloides, R. idaeus, D. dilatata, S. virgaurea, $S$. ovatus, $P$. purpurea). An individual was considered a single shoot (leaf) of $D$. dilatata species, rosette of L. luzuloides (s) sterile leaves, and rosette of L. luzuloides (f) with fertile stems. Green twigs or shoots growing from creeping root were sampled from $V$. myrtillus and $R$. idaeus. Aboveground stems were taken from $P$. purpurea, S. ovatus, and S. virgaurea.

The sampled material was dried at $85^{\circ} \mathrm{C}$ for 48 hours and homogenized with a planetary micro mill Fritsch $(<0.001 \mathrm{~mm})$. The total contents of $\mathrm{Cr}$ and $\mathrm{Ni}$ in plant shoots were determined after microwave mineralization of non-washed plant samples in concentrated $\mathrm{HNO}_{3}$ by an ETA-AAS using a Varian Spectr. AA 300/400 (samples were taken from relatively un-dusty areas, and washing the material runs the risk of leaching elements from damaged assimilatory organs of plants).

\section{Data Analysis}

Statistical analyses were made with the use of Statistica 9 software (Tulsa, USA). Transfer coefficients (TC) were calculated as a ratio of element concentration in plant 
species to the concentration of the same element in the soil [31-32]. Ratios higher than one indicate that plants are with high probability enriched with pollutants. The contents of heavy metal in plant shoots were compared with each other using one-way ANOVA. Relationships between contents of risk elements in topsoil layers and plant shoots sampled along an altitudinal transect were evaluated with linear regression analysis.

\section{Results and Discussion}

\section{Cr Concentrations in Topsoil and Plants}

The Cr concentrations in soils showed variations between the sites (Fig. 2a). For a more transparent depiction of $\mathrm{Cr}$ content in Ao horizons we used the second degree of polynomial. The results showed that mean $\mathrm{Cr}$ concentrations found in organo-mineral horizons of transect grew steadily to an altitude of $960 \mathrm{~m}\left(3.16 \pm 0.30 \mathrm{mg} \mathrm{kg}^{-1}\right)$ and upwards as they decreased (the mean value found in the highest plot was approximately 2.5 times lower). Similarly, $\mathrm{C}$ content in Ao horizons grew steadily to an altitude of $960 \mathrm{~m}$ and upwards as it declined (Table 1). On the other hand, Cr concentrations found in the horizons of surface humus (range $0.38 \pm 0.04-2.18 \pm 0.22 \mathrm{mg} \mathrm{kg}^{-1}$ ) decreased with increasing altitude. The relationship between $\mathrm{Cr}$ content and $\mathrm{pH} \mathrm{H}_{2} \mathrm{O}$ hinted that strongly acidic podzols contained less chromium than less acidic cambisols. $\mathrm{Cr}$ amounts detected in surface humus and Ao horizons of soils along altitudinal gradient were generally low as reference values stated in [33], while [34] stated that the
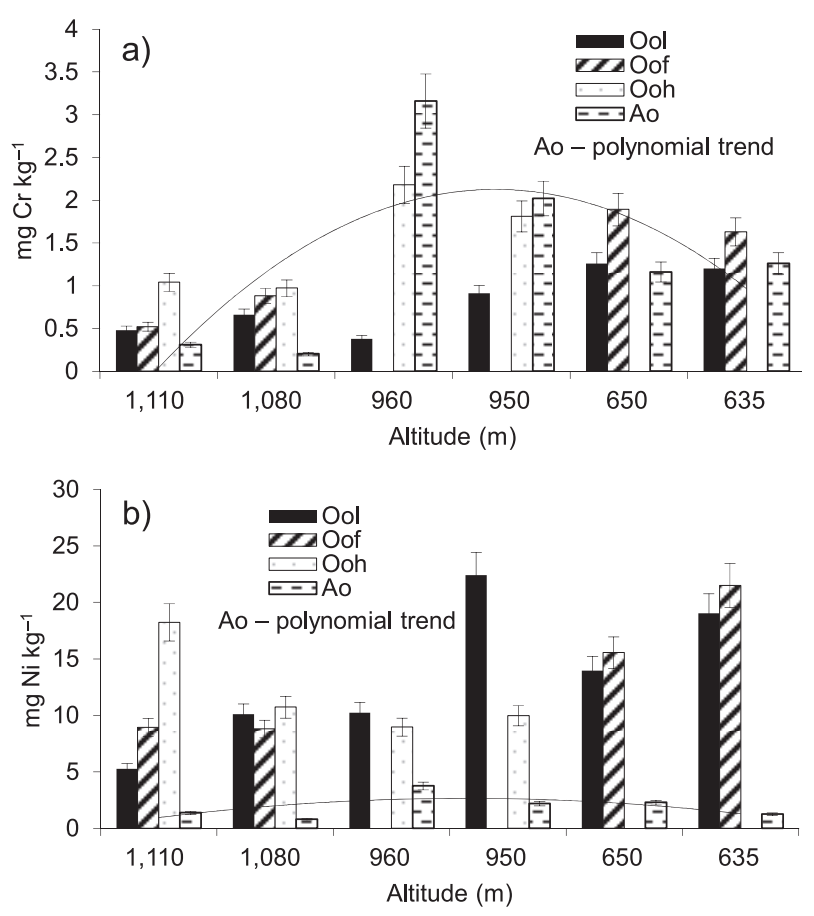

Fig. 2. Mean $\mathrm{Cr}$ a) and $\mathrm{Ni} \mathrm{b}$ ) concentrations in topsoil layers along an altitudinal gradient $(\mathrm{Oo}=$ subhorizons of surface humus, $\mathrm{Ao}=$ organo-mineral horizons, $\mathrm{n}=3$ ). range of bioavailable $\mathrm{Cr}$ content in Łódź allotment garden soil is changed from 1.51 to $12.91 \mathrm{ppm}$, and total $\mathrm{Cr}$ content ranges from 22.14 to $32.33 \mathrm{ppm}$. Samples were collected from the surface layer of soil at $0-20 \mathrm{~cm}$.

The accumulation of $\mathrm{Cr}$ in plant shoots varied widely due to the complex process of metabolism, but also the specific soil environment enhanced the availability of heavy metals to plant species (Fig. 3). Contents of $\mathrm{Cr}$ in $D$. dilatata and $R$. idaeus shoots grew to an altitude of $960 \mathrm{~m}$ and then more or less declined. V. myrtillus species showed at its absolute maximum $\left(1.13 \pm 0.11 \mathrm{mg} \mathrm{kg}^{-1}\right)$ on the highest plot, which could indicate the higher ability of the species to accumulate $\mathrm{Cr}$. Coefficients of variation in the plant species were relatively volatile (varying from 14 to $81 \%$ ). The largest fluctuation of $\mathrm{Cr}$ contents was found in $S$. ovatus species and the smallest in V. myrtillus. Based on the ability to accumulate $\mathrm{Cr}$, the studied plants can be ranked in the following descending series: V. myrtillus $>L$. luzuloides $(\mathrm{s})>$ L. luzuloides $(\mathrm{f})>P$. purpurea $>S$. ovatus $>S$. virgaurea $>R$. Idaeus $>D$. dilatata. The results showed that every plant species is in its own way specific and can accumulate different amounts of elements. The highest mean content of $\mathrm{Cr}$ found in $V$. myrtillus species was not significantly different from contents in other studied plants ( $p>0.05$; Fig. 3 ).

Higher contents of $\mathrm{Cr}$ in plant shoots are reflected in the higher transfer coefficients (TC) (Fig. 5). Cr was significantly cumulated in $V$. myrtillus species (TC 3.6 at altitude $1,110 \mathrm{~m}$ ) and $L$. luzuloides species (TC 1.15 at altitude $960 \mathrm{~m}$ ). Plants growing at 635-650 m are shown as worse $\mathrm{Cr}$ accumulators. [35] studied bioaccumulation characteristics of Nasturtium officinale species exposed to $\mathrm{Cr}$ and they also found relatively low bioconcentration factors for this species grown in different metal concentrations.

Presented data with the exception of $V$. myrtillus species at altitude $1,110 \mathrm{~m}$ showed higher $\mathrm{Cr}$ contents in Ao horizons of soils compared to plants. [36] argues that only a very small fraction of the total $\mathrm{Cr}$ content in soils is plant-available. According to [37], mobility of $\mathrm{Cr}$ is low in many plant species because plants have barriers to $\mathrm{Cr}$ transport. In most cases the plants growing on podzols contained less $\mathrm{Cr}$ than on Cambisols. This fact could be explained by the higher content of humus in Ao horizons of podzols, where the biological reduction of $\mathrm{Cr}$ by organic matter occurs. On the other hand, faster decomposition of soil organic matter of less acidic cambisols may result in the $\mathrm{Cr}$ amount becoming more available to plants. Similar findings were noted by [38]. According to [6], above, all presence of $\mathrm{Cr}$ in the external environment leads to changes in the growth and development pattern of the plants.

The $\mathrm{Cr}$ concentrations in topsoils and plants found along the altitudinal gradient showed positive stronger linear dependence for sterile shoots of $L$. luzuloides $(\mathrm{R}=0.506)$ and $D$. dilatata shoots $(\mathrm{R}=0.603)$. For other plant species we found the regression correlations to be insignificant (Table 2). Also, [39] indicated that plant uptake of $\mathrm{Cr}$ accounted for less than $1 \%$ of the $\mathrm{Cr}$ that was removed from the soil. 


\section{Ni Concentrations in Topsoil and Plants}

A different situation was recorded in evaluation of Ni content in soils (Fig. 2b). As a rule, substantially higher values showed horizons of surface humus compared to
Ao horizons of soils. The highest $\mathrm{Ni}$ values were detected in Ool horizons of soils (19.05 $\pm 1.72-22.41 \pm 2.02$ $\mathrm{mg} \mathrm{kg}$ ) situated at $635-950 \mathrm{~m}$ a.s.l. The trend of $\mathrm{Ni}$ content in Ao horizons was expressed by means of a polynomial of degree 2 . The highest content of $\mathrm{Ni}$
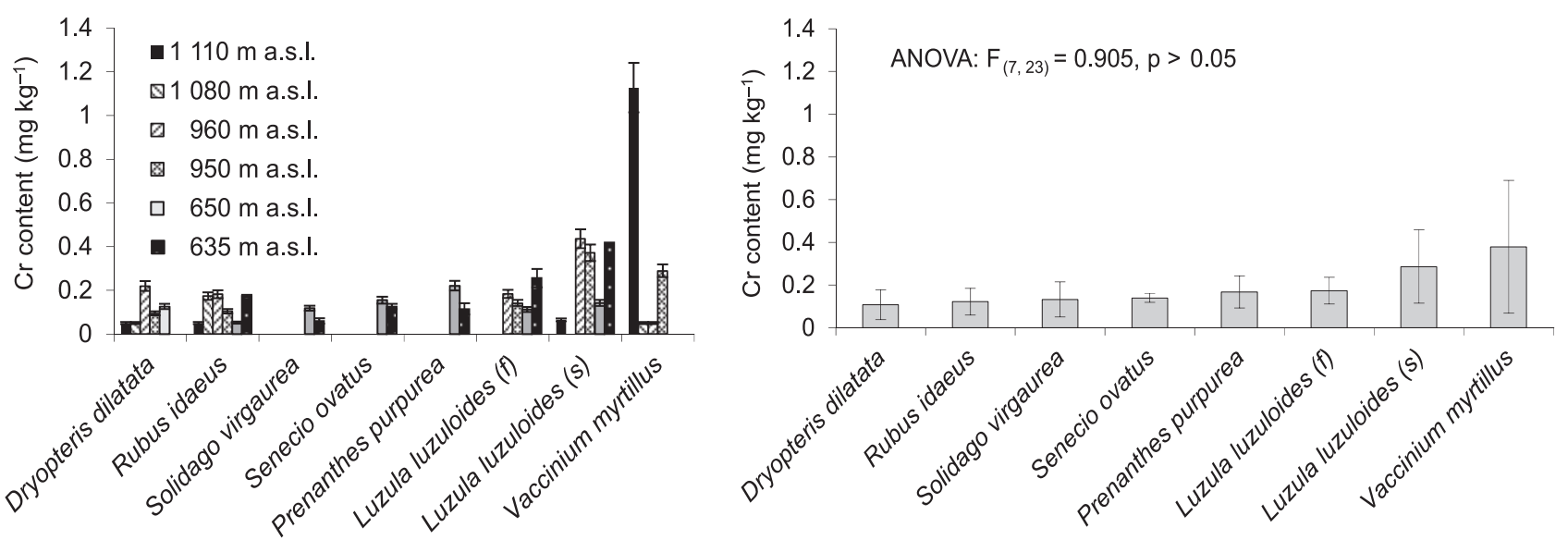

Fig. 3. Means and standard deviations of Cr concentrations in plant shoots sampled along an altitudinal gradient (f: fertile, s: sterile shoot, $\mathrm{n}=3$ ).

Table 2. The linear correlation between $\mathrm{Cr}$ contents in topsoil layers and plants.

\begin{tabular}{|c|c|c|c|c|c|}
\hline Characteristics & $\mathrm{n}$ & F-ratio & $\begin{array}{c}\text { Correlation coefficient } \\
(\mathrm{R})\end{array}$ & $\begin{array}{c}\text { R-squared } \\
\left(\mathrm{R}^{2}\right)\end{array}$ & Probability level \\
\hline Vaccinium myrtillus & 14 & 1.699 & 0.352 & 0.124 & $>0.05$ \\
\hline Luzula luzuloides (sterile) & 16 & 4.824 & 0.506 & 0.256 & $<\mathbf{0 . 0 5}$ \\
\hline Luzula luzuloides (fertile) & 12 & 0.015 & 0.039 & 0.001 & $>0.05$ \\
\hline Rubus idaeus & 20 & 0.603 & 0.180 & 0.032 & $>0.05$ \\
\hline Dryopteris dilatata & 17 & 8.584 & 0.603 & 0.322 & $<\mathbf{0 . 0 1}$ \\
\hline Solidago virgaurea & 8 & 0.779 & 0.317 & 0.100 & $>0.05$ \\
\hline Senecio ovatus & 8 & 0.077 & 0.137 & 0.019 & $>0.05$ \\
\hline Prenanthes purpurea & 8 & 0.076 & 0.136 & 0.018 & $>0.05$ \\
\hline
\end{tabular}
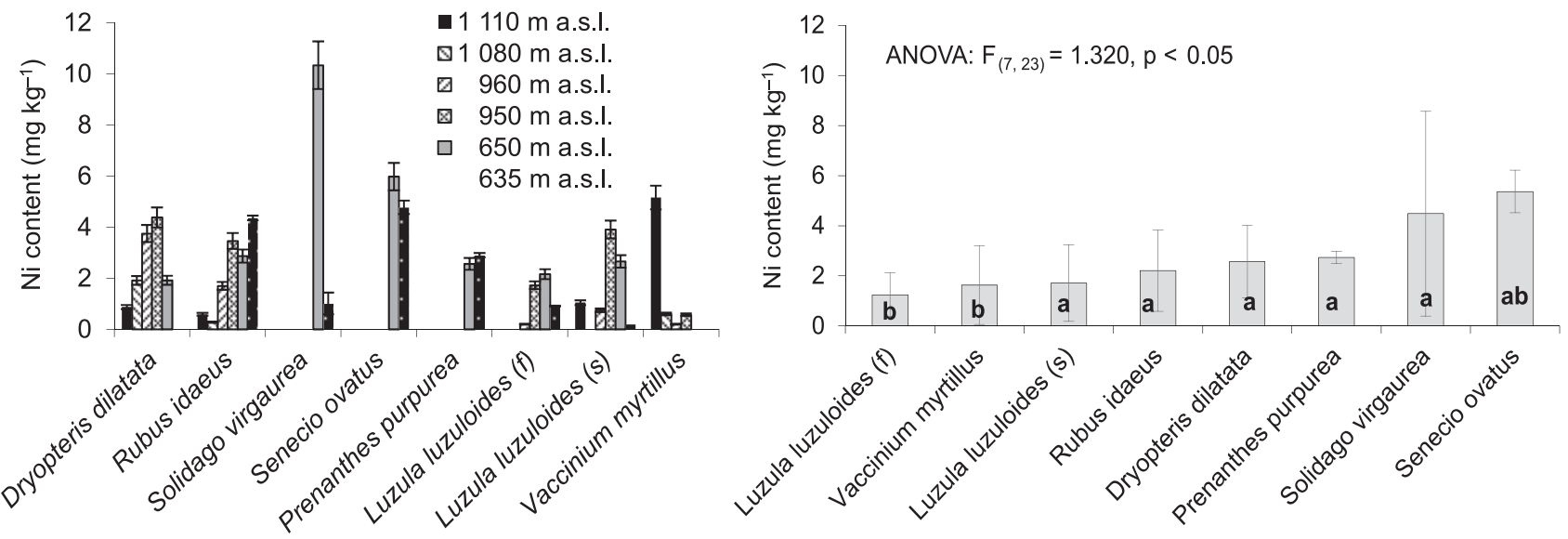

Fig. 4. Means and standard deviations of Ni concentrations in plant shoots sampled along an altitudinal gradient (f: fertile, s: sterile shoot, $\mathrm{n}=3$; no significant differences for values with the same letters). 
(3.75 $\left.\pm 0.34 \mathrm{mg} \mathrm{kg}^{-1}\right)$ was found in cambisol situated at $960 \mathrm{~m}$ altitude, and upwards decreased. The relationship between $\mathrm{Ni}$ content and $\mathrm{pH} \mathrm{H}_{2} \mathrm{O}$ of Ao horizons showed that strongly acidic podzols contained slightly less $\mathrm{Ni}$ than cambisols. Ni concentrations were closely related to the
$\mathrm{C}$ contents in soils - similar to $\mathrm{Cr}$. Contents of $\mathrm{Cr}$ and $\mathrm{Ni}$ depended especially on the ecological condition of soils ( $\mathrm{pH}$ value, humus content) corresponding to the changes of climate in altitudinal transect. Lower soil temperature at higher altitudes slows the rate of decomposition of surface
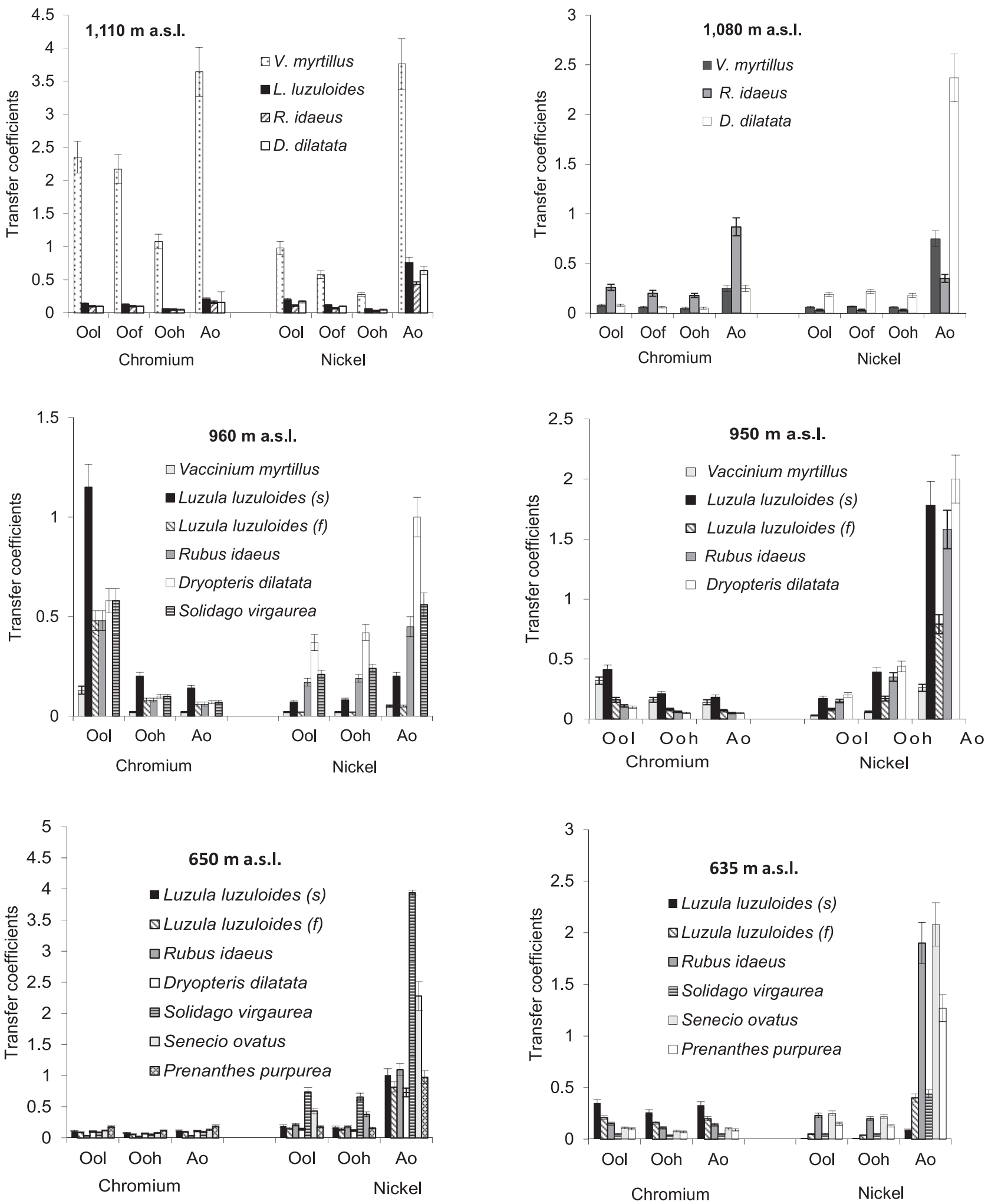

Fig. 5. Cr and Ni transfer coefficients (plant/soil) found along an altitudinal gradient $(\mathrm{Oo}=$ subhorizons of surface humus, Ao $=$ organomineral horizons, f: fertile, s: sterile shoot, mean \pm standard deviation, $\mathrm{n}=3$ ). 
Table 3. The linear correlation between Ni contents in topsoil layers and plants.

\begin{tabular}{|c|c|c|c|c|c|}
\hline Characteristics & $\mathrm{n}$ & F-ratio & $\begin{array}{c}\text { Correlation coefficient } \\
(\mathrm{R})\end{array}$ & $\begin{array}{c}\text { R-squared } \\
\left(\mathrm{R}^{2}\right)\end{array}$ & Probability level \\
\hline Vaccinium myrtillus & 14 & 0.005 & 0.020 & 0.003 & $>0.05$ \\
\hline Luzula luzuloides (sterile shoots) & 16 & 0.009 & 0.026 & 0.006 & $>0.05$ \\
\hline Luzula luzuloides (fertile shoots) & 12 & 0.124 & 0.111 & 0.012 & $>0.05$ \\
\hline Rubus idaeus & 20 & 2.215 & 0.331 & 0.110 & $<\mathbf{0 . 0 5}$ \\
\hline Dryopteris dilatata & 17 & 0.154 & 0.101 & 0.010 & $>0.05$ \\
\hline Solidago virgaurea & 8 & 0.026 & 0.061 & 0.004 & $>0.05$ \\
\hline Senecio ovatus & 8 & 0.239 & 0.237 & 0.056 & $>0.05$ \\
\hline Prenanthes purpurea & 8 & 0.240 & 0.238 & 0.055 & $>0.05$ \\
\hline
\end{tabular}

humus and the release of $\mathrm{N}$. The study of a migration of toxic elements in the Ukrainian Carpathian forests [40] also showed decreasing $\mathrm{Cr}$ and $\mathrm{Ni}$ concentrations in soils with altitude. It was highest in the oak forests, lower in beech forests, and the lowest in the zone of spruce forests. Amounts of $\mathrm{Ni}$ detected in Ao horizons of soils were relatively low and soils of altitudinal transect were not contaminated with Ni. However, the amounts of Ni higher than $10 \mathrm{mg} \mathrm{kg}^{-1}$ - excessive within the meaning of [33] were recorded in the surface humus horizons of soils in all studied forest stands.

Higher contents of $\mathrm{Ni}$ were in plants growing to altitude $960 \mathrm{~m}$ and upwards as Ni content in plants mostly declined (approximately 1.5 to 4 times). An exception was only $V$. myrtillus species on the highest situated plot, which may indicate the advanced ability of this species to accumulate Ni, as in the case of $\mathrm{Cr}$ (Fig. 4). An extremely high amount of $\mathrm{Ni}$ was observed in shoots of $S$. virgaurea $\left(10.33 \pm 0.93 \mathrm{mg} \mathrm{kg}{ }^{-1}\right)$. Ni concentrations detected in two of the plants growing on podzols ( $V$. myrtillus and $D$. dilatata) exceeded content reported for reference plants [25]. In the case of plants growing on cambisols the reference value for $\mathrm{Ni}$ was exceeded in six species. The $V$. myrtillus species seems to be resistant to the toxic effects of Ni. Ni coefficients of variation in the plants were markedly volatile (varying from 9 to 144\%). The least fluctuations of Ni were in P. purpurea species, and the most in $V$. myrtillus and $S$. virgaurea. Based on the ability to accumulate $\mathrm{Ni}$, the studied plants can be ranked in the following descending series: $S$. ovatus $>S$. virgaurea $>$ P. purpurea $>D$. dilatata $>R$. idaeus $>$ L. luzuloides (s) $>V$. myrtillus $>$ L. luzuloides (f). The Ni content in $S$. ovatus species was significantly different from contents in L. luzuloides (f) and V. myrtillus species ( $\mathrm{p}<0.05$; Fig. 4).

Our results showed higher levels of Ni toxicity on cambisols compared to the podzols. This can again be explained by faster decomposition of soil organic matter of less acidic cambisols and by higher Ni amounts becoming more available to plants. The uptake of $\mathrm{Ni}$ by plants depends especially on soil pH [41]. Similarly, [42] linked the separate effects of $\mathrm{pH}$ on sorption of $\mathrm{Ni}$ by soil and plant (increasing $\mathrm{pH}$ of soil enhances the availability of $\mathrm{Ni}$ for plants). Our results are consistent with these findings.

The values of transfer coefficients for $\mathrm{Ni}$ were higher compared to $\mathrm{Cr}$, which confirms the tendency of $\mathrm{Ni}$ to have elevated accumulation in plants (Fig. 5). On plots situated in an altitude higher than $1,000 \mathrm{~m}$, most Ni was transferred from the Ao horizons into $V$. myrtillus and D. Dilatata shoots (TC 3.76, resp. 2.37). On lower situated plots (950-960 m a.s.1.) most Ni was transferred into L. luzuloides sterile shoots (TC 1.78), and shoots of R. idaeus (TC 1.58) and D. dilatata species (TC 1-2). At 635-650 m Ni preferably cumulated species as $R$. idaeus (TC 1.1-1.9), S. virgaurea (TC 3.9), S. ovatus (TC > 2), and $P$. purpurea (TC 1.3). Similarly, [43] recorded Ni as the metal with high mobility from roots to leaves of plants within populations from inland and maritime saline areas, while $\mathrm{Cr}$ was evaluated as less mobile.

The relationship between Ni concentrations in topsoils and plants growing along the altitudinal gradient hinted moderate linear dependence $(\mathrm{R}=0.331)$ for $R$. idaeus species (Table 3 ). In the case of other plants we found insignificant regression correlations. Our results are not quite consistent with those published by [17], which studied toxicity threshold for Avena sativa species grown in Ni-impacted agricultural soils near Port Colborne, Ontario, Canada. The authors found that the relationship between $\mathrm{Ni}$ concentrations in soil and in tissue was less closely related to chemically extracted soil $\mathrm{Ni}$ (in two different extractions) than it was to a combination of total soil Ni. However, good correlation of $\mathrm{Ni}$ content in leaves with the concentration of metal in soil $(\mathrm{R}=0.661)$ showed Plantago major species growing near the Adriatic shore in western Albania [44].

\section{Conclusions}

The influence of climate, but also specific soilecological conditions ( $\mathrm{pH}$, humus, nutrient contents) showed varying ability of plants accumulating $\mathrm{Cr}$ and $\mathrm{Ni}$ along the altitudinal gradient. Contents of $\mathrm{Ni}$ in Ool and Oof horizons of surface humus with altitude as a rule 
decreased, while in Ooh the horizon increased. In the case of $\mathrm{Cr}$ a similar dependence was not observed. The contents of $\mathrm{Cr}$ found in surface humus and Ao horizons of Skeli-Humic podzols and dystric cambisols were nearly the same. The excessive amounts of $\mathrm{Ni}$ were recorded in the surface humus horizons of soils in all studied forest stands. The contents of $\mathrm{Cr}$ in plants were usually low, with the exception of $V$. myrtillus $\left(>1.1 \mathrm{mg} \mathrm{kg}^{-1}\right.$ ) growing at $1,110 \mathrm{~m}$ a.s.1. On the other hand, Ni contents were mostly higher than plant background value $\left(1.5 \mathrm{mg} \mathrm{kg}^{-1}\right)$. In the case of $S$. virgaurea at $650 \mathrm{~m}$ a.s.l it was more than $10 \mathrm{mg} \mathrm{kg}^{-1}$. The highest mean $\mathrm{Ni}$ content was found in $S$. ovatus shoots, and it significantly $(\mathrm{p}<0.05)$ differed from those found in $V$. myrtillus and L. luzuloides (fertile shoots). Stronger positive linear correlations were between $\mathrm{Cr}$ content in soils and shoots of $D$. dilatata and L. luzuloides (sterile shoots). For $\mathrm{Ni}$, it was $R$. idaeus. $\mathrm{Ni}$ transfer coefficients found for five plants (L. luzuloides - sterile shoots, R. idaeus, D. dilatata, S. ovatus, $S$. virgaurea) rooted in surface horizons of cambisols were higher than 1 , thus pointing at the impact of soil contamination. $\mathrm{Cr}$ transfer coefficients higher than 1 were found for D. dilatata (2.4) and $V$. myrtillus species (1.1.-3.6) rooted in the surface horizons of podzols, indicating the better bio-accumulation ability of these plant species.

\section{Acknowledgements}

This research was supported by the Scientific Grant Agency of the Ministry of Education of the Slovak Republic and of the Slovak Academy of Sciences (VEGA No. 2/0027/13).

\section{References}

1. WEI B., YANG L. A review of heavy metal contaminations in urban soils, urban road dusts and agricultural soils from China. Microchem. J., 94, 99, 2010.

2. KHAN Z.I., AHMAD K., RAZA N., AL-QURAINY F., ASHRAF M., HUSSAIN A. Assessment of chromium concentrations in soil-plant-animal continuum: possible risk for grazing cattle. Pak. J. Bot., 42, 3409, 2010.

3. SZABÓ S., SZABÓ G., BIHARI Á. Effects of acid loadings on heavy metal mobilization in cambisols. Annales Geographicae, 40, 72, 2007.

4. IYAKA Y.A. Chromium in Soils: A Review of its Distribution and Impacts. C. J. Env. Sci., 3, 13, 2009.

5. SINAM G., SINHA S., MALLICK S. Effect of chromium on accumulation and antioxidants in Cucumis utillissimus L.: Response under enhanced bioavailability condition. J. Environ. Sci., 23, 506, 2011.

6. SHANKER A.K., CERVANTES C., LOZA-TAVERA H., AVUDAINAYAGAM S. Chromium toxicity in plants. Environ. Int., 31, 739, 2005.

7. ANDJELKOVIĆ D.H., ANDJELKOVIĆ T.D., NIKOLIĆ R.S., PURENOVIĆ M.M., BLAGOJEVIĆ S.D., BOJIĆ A.L.J., RISTIĆ M.M. Leaching of chromium from chromium contaminated soil - a speciation study and geochemical modeling. J. Serb. Chem. Soc.,77, 119, 2012.

8. FOZIAA., MUHAMMAD A.Z, MUHAMMAD A., ZAFAR M.K. Effect of chromium on growth attributes in sunflower (Helianthus annuus L.). J. Environ. Sci., 20, 1475, 2008.

9. NOURI J., KHORASANI N., LORESTANI B., KARAMI M., HASSANI A.H., YOUSEFI N. Accumulation of heavy metals in soil and uptake by plant species with phytoremediation potential. Environ. Earth. Sci., 59, 315, 2009.

10. JUN R., LING T., GUANGHUA Z. Effects of chromium on seed germination, root elongation and coleoptile growth in six pulses. Int. J. Environ. Sci. Tech., 6, 571, 2009.

11. BUDAK F., ZAIMOĞLU Z., BAŞCI N. Uptake and translocation of hexavalent chromium by selected species of ornamental plants. Pol. J. Environ. Stud., 20, 857, 2011.

12. MORENO D.A., VÍLLORA G., SORIANO M.T., CASTILLA N., ROMERO L. Sulfur, chromium, and selenium accumulated in Chinese cabbage under direct covers. J. Environ. Manage., 74, 89, 2005.

13. SAMPANPANISH P., TIPPAYASAK K., CHAIRAT-UTAI P. Chromium accumulation by phytoremediation with monocot weed plant species and a hydroponic sand culture system. J. Environ. Res. Develop., 4, 654, 2010.

14. MISHRA S., SINGH V., SRIVASTAVA S., SRIVASTAVA R., SRIVASTAVA M.M., DASS S., SATSANGI G.P., PRAKASH S. Studies on uptake of trivalent and hexavalent chromium by maize (Zea mays). Food Chem. Toxicol., 33, 393, 1995.

15. KABATA-PENDIAS A. Trace elements in soils and plants, $4^{\text {th }}$ ed. CRC Press, Taylor and Francis Group, USA, pp. 505, 2010.

16. ROONEY C.P., ZHAO F-J., MCGRATH S.P. Phytotoxicity of nickel in a range of European soils: Influence of soil properties, Ni solubility and speciation. Environ. Pollut., 145, 596, 2007.

17. DAN T., HALE B., JOHNSON D., CONARD B., STIEBEL B., VESKA E. Toxicity thresholds for oat (Avena sativa $\mathrm{L}$.) grown in Ni-impacted agricultural soils near Port Colborne, Ontario, Canada. Can. J. Soil Sci., 88, 389, 2008.

18. KUKIER U., PETERS C.A., CHANEY R.L., ANGLE J.S., ROSEBERG R.J. The effect of $\mathrm{pH}$ on metal accumulation in two Alyssum Species. J. Environ. Qual., 33, 2090, 2004.

19. SEREGIN I.V., KOZHEVNIKOVA A.D. Physiological role of nickel and its toxic effects on higher plants. Russ. J. Plant Physiol., 53, 257, 2006.

20. TAKÁČ P., KOZÁKOVÁ L’, VALKOVÁ M., ZELEŇÁK F. Heavy metals in soils in middle Spiš. Acta Montanistica Slovaca, 13, 82, 2008.

21. KUKLA J., KUKLOVÁ M. Impact of long-term cultivation of spruce monocultues on development of forest soils. Beskydy, 4, 161, 2011.

22. KUKLOVÁ M., KUKLA J., HNILIČKA F. The soil-toherbs transfer of heavy metal in spruce ecosystems. Pol. J. Environ. Stud., 19, 1263, 2010.

23. KUKLOVÁ M., KUKLA J. Growth of Vaccinium myrtillus L. (Ericaceae) in spruce forests damaged by air pollution. Pol. J. Ecol., 56, 149, 2008.

24. KUKLOVÁ M., KUKLA J. Transfer of risk elements in soilbilberry system. Ekológia (Bratislava), 32, 211, 2013.

25. MARKERT B. Instrumental multielement analysis in plant materials, Série Tecnologia Ambiental 8, Rio de Janeiro, 1995.

26. ZHONG M., WANG J., LIU K., WU R., LIU Y., WEI X., PAN D., SHAO X. Leaf morphology shift of three dominant species along altitudinal gradient in an alpine meadow of the Qinghai-Tibetan plateau. Pol. J. Ecol., 62, 639, 2014. 
27. ZLATNÍK A. The survey of groups of types of geobiocoens originally forest and shrubby in the C.S.S.R. Zprávy Geografického ústavu CSAV, 13, 55, 1976 [In Czech].

28. ZLATNÍK A. FORESTRY PHYTOCOENOLOGY, SZN Praha, 1976 [In Czech].

29. SOCIETAS PEDOLOGICA SLOVACA. Morphogenetic soil classification system of Slovakia. Basal reference taxonomy. NPPC - VUPOP Bratislava, 96, 2014 [In Slovak].

30. IUSS Working Group WRB. World Reference Base for Soil Resources 2014, update 2015. International soil classification system for naming soils and creating legends for soil maps. World Soil Resources Reports 106, FAO, Rome, 193, 2015.

31. CHOJNACKA K., CHOJNACKI A., GÓRECKA H., GÓRECKI H. Bioavailability of heavy metals from polluted soils to plants. Sci. Total Environ., 337, 175, 2005.

32. ROSSINI OLIVA S., FERNÁNDEZ ESPINOSA A.J. Monitoring of heavy metals in topsoils, atmospheric particles and plant leaves to identify possible contamination sources. Microchem. J., 86, 131, 2007.

33. DECISION of the Ministry of Agriculture of the Slovak Republic on maximum allowable values of harmful substances in soil and on designation of organisations qualified to detect the real values of these substances, 531/1994-540. Bulletin of MP SR, 1994 [In Slovak].

34. JANKIEWICZ B., PTASZYŃSKI B. Determination of Chromium in Soil of Łódź Gardens. Pol. J. Environ. Stud., 14, 869, 2005.

35. DUMAN F., LEBLEBICI Z., AKSOY A. Growth and bioaccumulation characteristics of watercress (Nasturtium officinale R. BR.) exposed to cadmium, cobalt and chromium. Chem. Speciation Bioavail., 21, 257, 2009.
36. ZAYED A.M., TERRY N. Chromium in the environment: factors affecting biological remediation. Plant Soil., 249,139, 2003.

37. ANSARI A.A, GILL S.S, GILL R., LANZA G.R., NEWMAN L. (eds.). Phytoremediation: Management of Environmental Contaminants. Springer International Publishing Switzerland, 348, 2015.

38. BARTLETT R.J., KIMBLE J.M. Behaviour of chromium in soils: II. Hexavalent forms. J. Environ. Qual., 5, 383, 1976.

39. BANKS M.K., SCHWAB A.P., HENDERSON C. Leaching and reduction of chromium in soil as affected by soil organic content and plants. Chemosphere, 62, 255, 2006.

40. SHPARYK Y.S., PARPAN V.I. Heavy metal pollution and forest health in the Ukrainian Carpathians. Environ. Pollut., 130, 55, 2004.

41. WU Y., HENDERSHOT W.H. The effect of calcium and $\mathrm{pH}$ on nickel accumulation in and rhizotoxicity to pea (Pisum sativum L.) root-empirical relationships and modeling. Environ. Pollut., 158, 1850, 2010.

42. WENG L., LEXMOND T.M., WOLTHOORN A TEMMINGHOFF E.J., VAN RIEMSDIJK W.H. Phytotoxicity and bioavailabilityof nickel: chemical speciation and bioaccumulation. Environ. Toxicol. Chem., 22, 2180, 2003.

43. MILIĆ D., LUKOVIĆ J., NINKOV J., ZEREMSKIŠKORIĆ T., ZORIĆ L., VASIN J., MILIĆ S. Heavy metal content in halophytic plants from inland and maritime saline areas. Cent. Eur. J. Biol., 7, 307, 2012.

44. BEKTESHI A., BARA G. Uptake of heavy metals from Plantago major in the Region of Durres, Albania. Pol. J. Environ. Stud., 22, 1881, 2013. 